\title{
ІННОВАЦІЙНІ ПІДХОДИ ДО ВИКОРИСТАННЯ РЕКЛАМИ ТА РR-TЕХНОЛОГІЙ В ГОТЕЛЬНО-РЕСТОРАННОМУ БІЗНЕСІ
}

\section{INNOVATIVE APPROACHES \\ TO THE USE OF ADVERTISINGAND PR-TECHNOLOGIES IN THE HOTEL AND RESTAURANT BUSINESS}

\author{
Лисюк Тетяна Василівна \\ кандидат педагогічних наук, доцент, \\ Волинський національний університет імені Лесі Українки \\ ORCID: https://orcid.org/0000-0003-1629-9652 \\ Терещук Оксана Степанівна \\ кандидат географрічних наук, доцент, \\ Волинський національний університет імені Лесі Українки \\ ORCID: https://orcid.org/0000-0001-8131-1270 \\ Демчук Ольга Андріївна \\ студентка, \\ Волинський національний університет імені Лесі Українки \\ ORCID: https://orcid.org/0000-0001-5524-4633 \\ Lysiuk Tetiana, Tereshchuk Oksana, Demchuk Olga \\ Lesya Ukrainka Volyn National University
}

\begin{abstract}
У статті розглянуто вплив реклами та PR-технологій на готельно-ресторанну індустрію. Проаналізовано есрективність використання соціальної мережі Instagram для просування готельно-ресторанного бізнесу. Розглянуто основні переваги та недоліки рекламної кампанії у мережі. Зважаючи на розвиток індустрії гостинності, реклама та PR-технології є основними засобами просування ресторанного бізнесу. Адже сучасна готельно-ресторанна сорера дуже динамічна, щодня відкриваються різноманітні заклади, яким з урахуванням зростаючої конкуренції потрібно просувати власний заклад за допомогою реклами і PR-акцій. Також, важливо, що за допомогою Інтернету і соціальних мереж можна розробляти різні види інтернет-реклами. Вельми актуальним на сьогодні у розвитку та популяризації ресторану чи готелю $є$ створення контенту для закладу, або ж як це називають Social Media Marketing (SMM).

Ключові слова: реклама, PR-технології, соціальні мережі, готельно-ресторанний бізнес, Social Media Marketing.
\end{abstract}

B статье рассмотрено влияние рекламы и PR-технологий в гостинично-ресторанной индустрии. Проанализирована эффрективность использования социальной сети Instagram для продвижения гостинично-ресторанного бизнеса. Рассмотрены основные приемущества и недостатки рекламной кампании в сети. Несмотря на развитие индустрии гостеприимства, реклама и PR-технологии являются основными средствами продвижения ресторанного бизнеса. Ведь современная гостинично-ресторанная индустрия очень динамичная, ежедневно открываются различные заведения, которым с учетом растущей конкуренции нужно продвигать собственное заведение с помощью различных реклам и PR-акций. Также, важно, что с помощью Интернета и социальных сетей можно разрабатывать различные виды интернет-рекламы. Весьма актуальным на сегодня в развитии и популяризации ресторана или гостиницы является создание контента для заведения, или как это называют Social Media Marketing (SMM).

Ключевые слова: реклама, PR-технологии, социальные сети, гостинично-ресторанний бизнес, Social Media Marketing.

The article considers the impact of advertising and PR-technologies on the hotel and restaurant industry. The effectiveness of using the social network Instagram to promote the hotel and restaurant business is analyzed. 
The main advantages and disadvantages of an online advertising campaign are considered. Due to the development of the hospitality industry, advertising and PR-technologies are the main means of promoting the restaurant business. After all, the modern hotel and restaurant industry is very dynamic, every day various establishments are opened, which, taking into account the growing competition, need to promote their own establishments and PR-promotions. Also, it is important that with the help of the Internet and social networks you can develop different types of online advertising. A very important aspect in the development and promotion of a restaurant or hotel is the creation of content for the institution or as it is called Social Media Marketing (SMM). In addition, competition in the market of hotel and restaurant services forces management to resort to various PR-technologies. As a rule, these are serious PR-actions and creation of the concept of the institution that meets the requirements of the modern market. Thus, in the article, we considered the effectiveness of advertising in the hotel and restaurant industry. However, the article raises the question of how to promote the restaurant in the service market. After all, how attractive and popular a restaurant is depends on its attendance and the number of regular customers. Therefore, the image and concept of the institution depends on advertising and PR-technologies. The main tasks of advertising activity and sequence of actions at the organization of advertising campaign are investigated. The article examines the main trends in the hotel and restaurant industry, which is one of the highly profitable industries of the tertiary sector of the economy, which ultimately requires successful promotion in the modern market. That is why advertising and PR-technologies in the hotel and restaurant business are a multifaceted and promising area. Its task is to promote the institution and build the trust of the guest in the long run.

Keywords: advertising, PR-technologies, social networks, hotel and restaurant business, Social Media Marketing.

Постановка проблеми. На сьогоднішній день, готельно-ресторанна ссрера - це одна 3 найбільш швидкозростаючих галузей. Міжнародний досвід свідчить, що необхідною передумовою активного та успішного просування цієї галузі на ринок держави є сучасна туристична інорраструктура. 3 кожним роком зростає кількість готелів та ресторанів, які вимагають успішного просування. Зрештою, жорстка конкуренція на ринку готельно-ресторанних послуг змушує керівництво застосовувати спеціальні заходи, які можуть звернути увагу потенційного гостя. Адже просування закладу залежить від індивідуальних особливостей гостя. Від того, наскільки привабливий ресторан, залежить його відвідуваність та обсяг продажів ресторанних послуг.

Аналіз останніх досліджень та публікацій. Дослідженню аспектів реклами та PR-технологій в готельно-ресторанному бізнесі присвячені праці таких вчених Балабанов Л.В. [1], Балабанов А.В. [2], Слісаренко І.Ю. [6], Почепцов Г.Г. [5], Тихомирова Є.Б. [7].

У зазначених працях авторів аналізується стан індустрії гостинності, висвітлюються проблеми застосування рекламних концепцій управління, а також проаналізовано питання застосування PR-технологій в готельно-ресторанному бізнесі.

Виділення невирішених раніше частин загальної проблеми. Більша частина науковців у своїх працях акцентує увагу на аналіз конкретних ситуацій при формуванні та здійсненні рекламної діяльності. Необхідне ретельне дослідження цільової аудиторії, партнерів, клієнтів та споживачів, з метою розробки загальних методів просування закладу, що сприяють залученню нових потенційних гостей.

Формулювання цілей статті. Основним завданням даної статті $€$ визначення особливостей PR-технологій, механізмів створення реклами та їх вплив на готельно-ресторанну copepy.

Виклад основного матеріалу, дослідження. На сьогоднішній день готельно-ресторанна індустрія $€$ однією з найбільш конкурентоспроможних, проте Covid-пандемія стала причиною консервації багатьох об'єктів розміщення. щоб зберегти частку ринку, не кажучи вже про зростання, готелям потрібні стратегічні зв'язки з громадськістю.

Готелі та ресторани повинні мати продуману комунікаційну стратегію і постійно підтримувати зв'язки з контактними аудиторіями і громадськістю. Комунікаційні процеси повинні бути безперервними і ефективними.

Найчастіше характер здійснення PR діяльності в готельно-ресторанному бізнесі залежить від специфіки, рівня і характеру надання послуг. Завдання PR полягає в тому, щоб налагодити взаєморозуміння, позитивне відношення і довіру клієнта до пропозицій підприємств готельно-ресторанного бізнесу на перспективу. Йдеться про формування в очах громадськості позитивного іміджу, хорошої репутації і поваги до підприємств [2].

3 кожним роком зростає кількість готелів та ресторанів як у нашій країні, так і за кордоном. Велика кількість ресторанів та готелів стикаються із жорсткою конкуренцією на ринку готельно-ресторанних послуг, і зрештою змушує менеджерів вдаватися до різних неординарних рекламних ідей. Більшість менеджерів 
ще просто не встигли опанувати цю незвичну область, адже зорієнтувати потенційного гостя на такому великому та різноманітному ринку послуг дуже важко.

Проте, вплив реклами та PR-технологій на готельно-ресторанну сореру очевидна. На сьогоднішній день ефрективність реклами почала знижуватись і виникла потреба у чомусь новому. Відбулося так зване перенасичення споживача рекламою взагалі і недовіра до неї призвела до того, що заклади розміщення та харчування постали перед проблемою пошуку нових шляхів приваблювання гостей. На сучасному етапі есрективним інструментом просування готельно-ресторанного бізнесу є соціальна мережа Instagram.

Instagram - це потужний інструмент для просування. Завдяки цій соціальній мережі у менеджерів підприємств сорери послуг $€$ доступ до величезної аудиторії гостей, 3 якими можна спілкуватися, залучати, ознайомлювати з послугами, що надаються [3].

Просування в соціальних мережах сприяє охопленню максимально широкої аудиторії. За допомогою реклами в соціальних мережах, підприємства можуть знаходити партнерів, співробітників, і таким чином сприяти розвитку свого бізнесу.

Загалом, зареєструвавши аккаунт закладу в Instagram, можна підвищити впізнаваність ресторану чи готелю, дізнатися про те, що думають користувачі про якість надаваних послуг у закладі. Що подобається, що потрібно покращити або виключити.

Таким чином, спілкуючись зі своєю аудиторією і поступово додаючи нову інсрормацію, можна створити вигідний імідж для підпри- ємств ссрери послуг. I для того щоб створити такий імідж, потрібен фрахівець який займається контентом для закладу. SMM-менеджер вирішує ряд складних завдань, пов'язаних із залученням потенційних споживачів 3 соціальних мереж, підвищенням іміджу закладу, а також популяризує послуги в закладі. Він створює та оформляє корпоративні сторінки в різних соціальних мережах, зацікавлює цільову аудиторію, відповідає на питання і коментарі потенційних гостей, займається просуванням закладу.

Справжній SMM-спеціаліст повинен розуміти, що рекламна інформація яка публікується, має бути цікавою та доступною. Однією 3 основних цілей використання соціальних мереж у маркетингу є комунікація, яка робить індустрію гостинності доступною для тих, хто зацікавлений у видах послуг, які надаються закладом, і робить їх доступними для тих, хто не знає про ці послуги.

Реклама в Інтернеті сьогодні набуває надзвичайно великого значення, проте має переваги і недоліки.

Сьогодні майже всі рекламні агентствапропонують своїм клієнтам таку послугу, як Інтернет реклама. Основна мета реклами в мережі - це створення позитивного іміджу готельно-ресторанних підприємств, залучити потенційних гостей і перетворити їх на постійних.

Для забезпечення стабільного ефективного фрункціонування підприємств індустрії гостинності необхідно розробити стратегію їх розвитку, метою якої буде досягнення максимально есрективних результатів, які безпосередньо вплинуть на діяльність готельно-ресторанних підприємств [4].

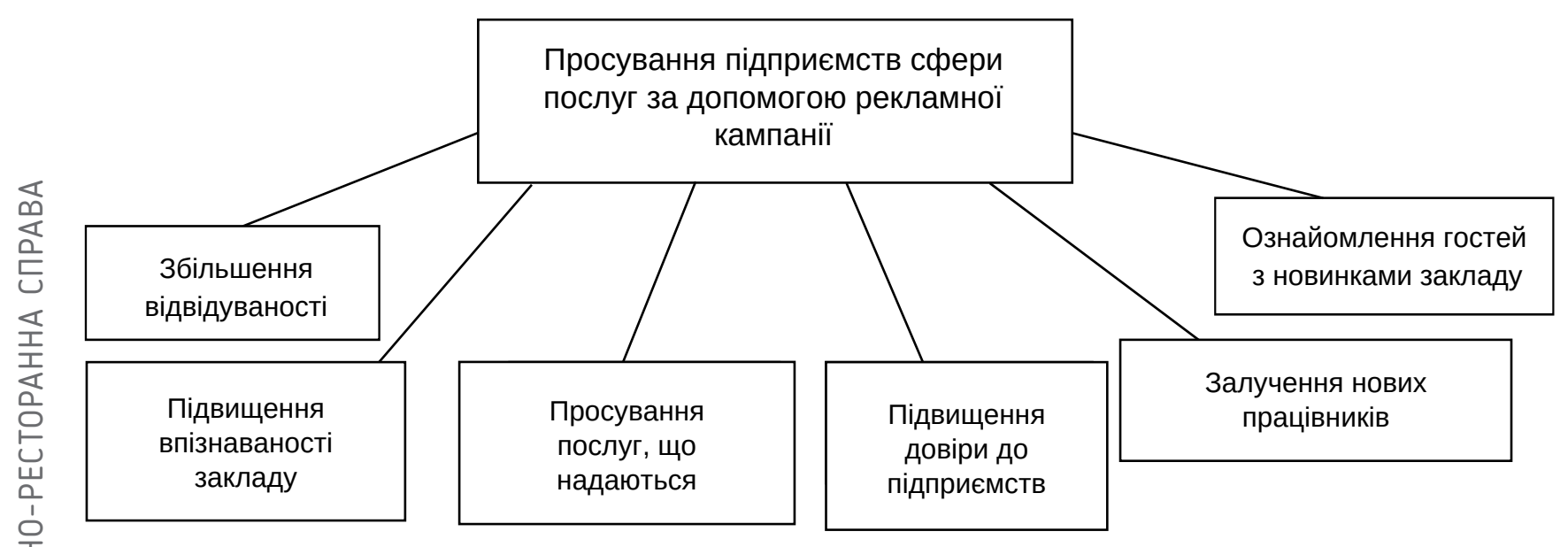

Рис. 1. Структура просування готельно-ресторанного бізнесу за допомогою рекламної кампанії в соціальній мережі Instagram 
Основні переваги та недоліки рекламної кампанії у мережі

Таблиця 1

\begin{tabular}{|l|l|}
\hline \multicolumn{1}{|c|}{ Переваги } & \multicolumn{1}{|c|}{ Недоліки } \\
\hline $\begin{array}{l}\text { Легке розташування реклами } \\
\text { для споживача }\end{array}$ & $\begin{array}{l}\text { У мережі велика конкуренція, і перш ніж } \\
\text { розміщувати рекламу, варто обміркувати } \\
\text { концепцію закладу }\end{array}$ \\
\hline Доступна ціна & Важко знайти надійний сайт \\
\hline $\begin{array}{l}\text { Більш за будь-який інший засіб } \\
\text { розміщення реклами привертає увагу } \\
\text { потенційних гостей }\end{array}$ & Працює тільки тоді, коли фрінансується \\
\hline Висока довіра користувачів & Вимагає довгострокових інвестицій \\
\hline Величезний простір для креативності & $\begin{array}{l}\text { Особлива обережність клієнтів до реклами, } \\
\text { які раніше не мали доступу до мережі, } \\
\text { і відповідно не могли оцінити їі ефективості }\end{array}$ \\
\hline $\begin{array}{l}\text { Можна скорегувати рекламу під свою } \\
\text { цільову аудиторію }\end{array}$ & \\
\hline $\begin{array}{l}\text { Можна відслідкувувати есективність } \\
\text { реклами після запуску, і відразу } \\
\text { вносити коригування, якщо результат } \\
\text { незадовільний }\end{array}$ & \\
\hline
\end{tabular}

Джерело: складено авторами

Слід зазначити, що ефективність реклами це невизначений і мінливий критерій. Адже, можна визначати ефрективність розміром прибутку або підвищеним інтересом до закладу.

Можна виділити наступні найпоширеніші види реклами для підвищення ефрективності підприємств індустрії гостинності:

- білборди;

- реклама на радіо;

- реклама на телебаченні;

- реклама на моніторах;

- реклама в Інтернеті.

Таким чином, оперативне використання різних видів реклами, допомагає підвищити есрективність та продуктивність роботи готельно-ресторанних комплексів. Адже реклама впливає на економічну та соціальну складові роботи готельно-ресторанної індустрії.

Головною умовою для успішного готельноресторанного бізнесу $€$ профресійне просування закладу на сучасному ринку послуг. Заклади індустрії гостинності повинні постійно впроваджувати інновації, щоб залишатись провідними у своєму сегменті та бути попереду свої конкурентів.

Просування закладів індустрії гостинності на ринку послуг, залежить від їх індивідуальних особливостей: напрямку кухні, цінової політики, розташування, якості обслуговування та інших фракторів. Від того, наскільки привабливий ресторан для відвідувачів, залежить його відвідуваність, кількість постійних клієнтів i, отже, обсяг продажів ресторанних послуг.

Серед методів просування закладів індустрії гостинності $€$ проведення спеціальних заходів. Найбільш використовуваними у практиці готельно-ресторанної індустрії $€$ наступні PR-акції [8]:

- благодійні заходи;

- проведення дитячих свят, національних подій і ін.;

- тижні кухонь різних регіонів;

- майстер-класи від шефр-кухаря;

- дегустації.

На сьогоднішній день ні одне підприємство не може існувати без належного просування. PR-технології допомагають створити позитивний імідж закладу, привести багато нових гостей та стати впізнаваним місцем, до якого завжди хочеться повернутись.

Основні завдання, які реалізуються під час здійснення реклами та PR-діяльності ресторану [8]:

- інфрормування потенційних гостей про ресторан;

- формування позитивного іміджу;

- проведення спеціальних заходів;

- підвищення лояльності клієнтів.

При організації рекламної кампанії у готельно-ресторанному бізнесі рекомендується наступна послідовність дій [8]:

- вивчити маркетингову ситуацію, проаналізувати конкурентні умови на ринку або його сегменті; 
- визначити цільову аудиторію, портрет потенційного гостя і перелік рекламованих послуг;

- сорормувати цілі рекламної кампанії;

- розробити рекламну стратегію: концепцію основної ідеї проведення рекламної кампанії;

- вибрати кошти на поширення реклами, періодичність та строки розміщення реклами;

- розрахувати кошторис витрат на рекламні заходи;

- визначити реальні розміри грошових коштів, які можна використовувати на рекламу і в залежності від цього провести коригування плану рекламної кампанії;

- остаточно узгодити потреби в рекламі 3 реальними можливостями ресторану на певний період (квартал, рік);

- розробити рекламні повідомлення і тексти;

- скласти поетапний план розміщення акцій і видання реклами;

- організувати роботу підприємств під час рекламної кампанії;

- оцінити ефрективність рекламної кампанії після її проведення.

Висновки. Ефрективність застосування реклами та PR-діяльності залишається актуальною і вимагає постійної уваги. Реклама та PR-технології $€$ важливим інструментом для просування послуг ресторану та готелю. Однак, забезпечення бажаного результату можливе лише в тому випадку, якщо реклама орієнтована на цільовий сегмент споживача.

Проте, засоби комунікації зі зв'язками 3 громадськістю, які були ефективними минулого року або навіть на початку цього року, дуже ймовірно, сьогодні не будуть практичними. Визнання ситуації є надзвичайно важливим, але наступним кроком $€$ переоцінка цих зусиль щодо PR та з'ясування того, як саме їх можна максимізувати, навіть серед поточних подій, що склалися.

Сучасний медіа-пейзаж та мінливий світ поставили готельно-ресторанний бізнес у скрутне становище, але впровадження сучасних методів PR може сприяти підвищенню довіри до бренду та поінсормованості, навіть в умовах усього хаосу. Зараз, як ніколи, готельно-ресторанній індустрії потрібні ефективні стратегічні комунікації, щоб мати можливість відійти від пандемії та економічного спаду.

Отож, на сучасному етапі важливо визнати, що застарілі методи у сорері зв'язків з громадськістю зараз не будуть результативними, а інноваційні методи та стратегії спілкування мають силу залучити більше гостей i, в свою чергу, принести значний прибуток готельноресторанним підприємствам.

\section{СПИСОК ВИКОРИСТАНИХ ДЖЕРЕЛ:}

1. Балабанов А.В. Цікаве медіапланування. Москва : РВП-Холдинг, 2000. 104 с.

2. Балабанов Л.В. Основи паблік рілейшнз : Навчальний посібник, Київ, 2001.

3. Гвозденко Є.М., Чекштуріна В.M. Instagram як ефективний інструмент просування бізнесу. Розвиток європейського простору очима молоді: економічні, соціальні та правові аспекти. м. Харків, 2019 року. Харків : ХНЕУ ім. С. Кузнеця, 2019.

4. Миронова М.І., Миронов Ю.Б. Показники ефективності діяльності підприємств індустрії гостинності: Матеріали Всеукраїнської науково-практичної конференції (м. Черкаси, 16-17 квітня 2020 р.). Черкаси, 2020. C. 517-520.

5. Почепцов Г.Г. Теорія комунікацій. Київ : ВЦ «Київськийуніверситет», 2015. 308 с.

6. Слісаренко І.Ю. Паблік рилейшнз у системі комунікації та управління: Навч. посіб. Київ : МАУП, 2017. $104 \mathrm{c}$.

7. Тихомирова Є.Б. Зв'язки з громадськістю : Навч. посіб. Київ : НМЦВО, 2011. 560 с.

8. Шутенко В.П., Голуб М. O. PR-технології у ресторанному бізнесі. Розвиток європейського простору очима молоді: економічні, соціальні та правові аспекти. м. Харків, 2019 року. Харків : ХНЕУ ім. С. Кузнеця, 2019.

\section{REFERENCES:}

1. Balabanov A.V. (2000) Cikave mediaplanuvannja [Interesting media planning]. Moskow: RVP-Kholdyngh. (in Russian)

2. Balabanov L.V. (2001) Osnovy pablik rilejshnz [Basic of PR]. Kyiv. (in Ukrainian)

3. Ghvozdenko Je.M., Chekshturina V.M. (2019) Instagram jak efektyvnyj instrument prosuvannja biznesu [Instagram as an effective tool for business promotion]. Kharkiv: KhNEU im. S. Kuznecja. (in Ukrainian) 
4. Myronova M.I., Myronov Ju.B. (2020) Pokaznyky efektyvnosti dijaljnosti pidpryjemstv industriji ghostynnosti [Indicators of efficiency of enterprises of the hospitality industry]. Cherkasy. (in Ukrainian)

5. Pochepcov Gh.Gh. (2015) Teorija komunikacij [Communication theory]. Kyiv: Kyjivsjkyj'universytet. (in Ukrainian)

6. Slisarenko I.Ju. (2017) Pablik rylejshnz u systemi komunikaciji ta upravlinnja [PR in the system of communication and management]. Kyiv: MAUP. (in Ukrainian)

7. Tykhomyrova Je.B. (2011) Zv'jazky z ghromadsjkistju [Public relations]. Kyiv: NMCVO. (in Ukrainian)

8. Shutenko V.P., Gholub M.O. (2019) PR-tekhnologhiji u restorannomu biznesi [PR-technologies in the restaurant business]. Kharkiv: KhNEU im. S. Kuznecja. (in Ukrainian) 